\title{
Nomenclatural notes on southern African Oxalis species
}

\begin{tabular}{|c|c|}
\hline \multicolumn{2}{|c|}{$\begin{array}{l}\text { Authors: } \\
\text { Leanne L. Dreyer }{ }^{1} \text { (D) } \\
\text { Kenneth C. Oberlander }{ }^{2} \\
\text { Ronell R. Klopper }\end{array}$} \\
\hline \multicolumn{2}{|c|}{$\begin{array}{l}\text { Affiliations: } \\
{ }^{1} \text { Department of Botany and } \\
\text { Zoology, Stellenbosch } \\
\text { University, South Africa }\end{array}$} \\
\hline \multicolumn{2}{|c|}{$\begin{array}{l}{ }^{2} \text { Department of Conservation } \\
\text { Ecology and Entomology, } \\
\text { Stellenbosch University, } \\
\text { South Africa }\end{array}$} \\
\hline \multicolumn{2}{|c|}{$\begin{array}{l}{ }^{3} \text { Biosystematics Research \& } \\
\text { Biodiversity Collections, } \\
\text { South African National } \\
\text { Biodiversity Institute, } \\
\text { Pretoria, South Africa }\end{array}$} \\
\hline \multicolumn{2}{|c|}{$\begin{array}{l}\text { Corresponding author: } \\
\text { Leanne Dreyer, Id@sun.ac.za }\end{array}$} \\
\hline \multicolumn{2}{|c|}{$\begin{array}{l}\text { Dates: } \\
\text { Received: } 23 \text { Oct. } 2017 \\
\text { Accepted: } 18 \text { May } 2018 \\
\text { Published: } 03 \text { July } 2018\end{array}$} \\
\hline \multicolumn{2}{|c|}{$\begin{array}{l}\text { How to cite this article: } \\
\text { Dreyer, L.C., Oberlander, } \\
\text { K.C. \& Klopper, R.R., 2018,' } \\
\text { Nomenclatural notes on } \\
\text { southern African Oxalis } \\
\text { species', Bothalia 48(1), } \\
\text { a2318. https://doi. } \\
\text { org/10.4102/abc.v48i1.2318 }\end{array}$} \\
\hline \multicolumn{2}{|c|}{$\begin{array}{l}\text { Copyright: } \\
\text { (C) 2018. The Authors. } \\
\text { Licensee: AOSIS. This } \\
\text { is licensed under the } \\
\text { Creative Commons } \\
\text { Attribution License. }\end{array}$} \\
\hline \multicolumn{2}{|l|}{ Read online: } \\
\hline 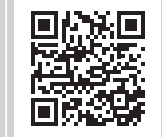 & $\begin{array}{l}\text { Scan this QR } \\
\text { code with your } \\
\text { smart phone or } \\
\text { mobile device } \\
\text { to read online. }\end{array}$ \\
\hline
\end{tabular}

Background: The correct author citation of Oxalis sonderiana (Kuntze) J.F.Macbr. and the validity and identity of the species Oxalis beneprotecta R.Knuth, Oxalis bullulata T.M.Salter and Oxalis pulchella Jacq. var. beneprotecta (R.Knuth) T.M.Salter are unclear.

Objectives: To resolve the nomenclatural and taxonomic confusion surrounding these four taxa.

Method: We studied relevant herbarium records (especially type material) of all the taxa, and paired this with scrutiny of all publications that bear reference to the nomenclature and taxonomy of these species.

Results: The correct author citation for Oxalis sonderiana has been determined; Oxalis bullulata is confirmed as a distinct species, and the continued recognition of Oxalis beneprotecta as a variety of Oxalis pulchella is suggested. It is further ascertained that the name 'Oxalis nidulans Turcz.' is not a later homonym, but a reference to a misapplication of Oxalis nidulans Eckl. \& Zeyh. to the type specimen of Oxalis sonderiana.

Conclusion: These results clarify the current confusion surrounding these taxa in global herbaria and in national and international databases.

\section{Correct author citation for Oxalis sonderiana}

In 1860, Sonder described the species Oxalis minima Sond. based on the specimen Zeyher 237 (Sonder 1860:312). This was an illegitimate later homonym, as the combination was already published for three other species of Oxalis, namely by Steudel (1821:579), by Don (1831:760) and by Ecklon and Zeyher (1835:92). Kuntze (1891:91) moved several Oxalis species to the genus Acetosella Kuntze. As the epithet 'minima' had already been assigned to one of the older species [Acetosella minima (Eckl. \& Zeyh.) Kuntze = O. minima Eckl. \& Zeyh.], Kuntze (1891:91) published a nomen novum for O. minima Sond., namely Acetosella sonderiana Kuntze. Knuth (1930:355) again treated all species under the genus Oxalis and lists this taxon as O. minima Sond. Macbride (1934:8) recognised that $O$. minima Sond. was an illegitimate superfluous name and corrected the name for the South African species while dealing with the South American O. minima G.Don. In doing this, Macbride (1934:8) unfortunately used an orthographical variant of the epithet and proposed the name Oxalis sonderana (Kuntze) J.F.Macbr. instead of 'sonderiana'. Two years later, Salter (1936:155) described a variety of this taxon as Oxalis minima Sond. var. alba T.M.Salter. Salter (1944) later revised the southern African members of Oxalis, including the taxon based on the Zeyher 237 type specimen. At some point between 1936 and the revision, he became aware that the original species epithet was preoccupied, and in Salter (1944:196), he thus superfluously proposed the name Oxalis sonderiana (Kuntze) T.M.Salter (an isonym) for this species. He appears to have been unaware of the publication by Macbride (1934), as he does not refer to it in his section entitled 'Previous Systematic Work' (Salter 1944:9).

The work of Salter (1944) has been widely accepted. For this reason, most South African databases [including those of the South African National Biodiversity Institute (SANBI), namely the Botanical Database of Southern Africa (BODATSA; www.newposa.sanbi.org) and the Red List of South African Plants (www.redlist.sanbi.org)], as well as the international database Tropicos (www. tropicos.org), list (or had listed, see below) this species with Salter as final author. In contrast, the International Plant Names Index (IPNI; www.ipni.org) recognises the publication by Macbride (1934:8) and thus correctly lists the species as Oxalis sonderiana (Kuntze) J.F.Macbr. This confusion is further exacerbated by notes to the effect that Macbride (1934:8) should be the author rather than Salter (1944:196) on the type specimen in Kew and yet it is listed as O. sonderiana (Kuntze) T.M.Salter in the Kew herbarium catalogue. In addition, an accession listed as Oxalis minima Sond. (collection Schlechter 7931, barcode K000419342!) on the same herbarium sheet is not this species, but is still 
listed as an accession of O. sonderiana (Kuntze) T.M.Salter. Salter (1944:198) identified the two plants (top right hand side on the sheet) comprising the Schlechter 7931 collection as Oxalis luteola Jacq., an identification with which we agree based on the visible bulb and sepal characters (http://apps.kew.org/ herbcat/getImage.do?imageBarcode=K0004193442 - accessed 07 June 2017).

Article 61.4 of the International Code of Nomenclature for Algae, Fungi and Plants (ICN; McNeill et al. 2012) states that:

The orthographical variants of a name are to be corrected to the validly published form of that name. Whenever such a variant appears in a publication, it is to be treated as if it appeared in its corrected form. (p. 122)

This means that the orthographical variant published by Macbride (1934:8) is to be treated as an error to be automatically corrected and, therefore, the publication by Macbride (1934:8) should be accepted as the first valid publication of the combination, given that it predates that of Salter (1944:196). The correct author citation for the species is thus Oxalis sonderiana (Kuntze) J.F.Macbr., as listed in IPNI and recently corrected in BODATSA.

Sonder (1860:20*, in a list of Addenda and Corrigenda) seems to be the first to cite the name 'O. nidulans, Turcz. Bull. Mosc. 1858. No. 2, p. 436 ' as a synonym of O. minima. McBride (1934:8) and Salter (1944:196) both list this name in synonymy, probably merely following Sonder (1860) and not referring to the original publication, as the Russian journal in which the article by Turczaninow (1858) was published would likely not have been easily available to them. Because of these publications, it is generally accepted, and also listed as such on IPNI, that the name 'O. nidulans Turcz.' is a later homonym. However, Turczaninow did not publish a new name, but specifically accredits the name to Ecklon \& Zeyher. He lists Zeyher 237 as being representative and mentions the following about the specimens in his herbarium:

Descriptio satis quadrat, praeter tuberculum in speciminibus meis deficientem [Compares well enough with the description, except for the lack of a tubercle (we interpret this to mean bulb) in my specimens]. (p. 436)

The lack of bulb material on Zeyher 237 undoubtedly contributed to the confusion, as the bulbs of $O$. nidulans and $O$. sonderiana differ markedly. We therefore believe that Turczaninow (1858:436) did not publish a new name, but merely misapplied the name O. nidulans Eckl. \& Zeyh. to Zeyher 237, which was later chosen as the type of O. minima by Sonder (1860:336). The mere mention of Zeyher 237 by Turczaninow (1858) does not constitute typification of O. nidulans Eckl. \& Zeyh. with this specimen, because he does not use the term 'type' or equivalent, nor does he provide explanation in this article that the specimens mentioned should be treated as types (Art. 7.10, McNeill et al. 2012). As Ecklon and Zeyher (1835:92) earlier cited a single collection from 'Pampoenekraal' in the protologue, this specimen (Ecklon $\mathcal{E}$ Zeyher 724) is the holotype of O. nidulans.
Oxalis sonderiana (Kuntze) J.F.Macbr. in Candollea 6: 8 (1934), as 'sonderana'; Acetosella sonderiana Kuntze in Revis. Gen. Pl. 1: 91 (1891); Oxalis nidulans auct. sensu Turcz. in Bull. Soc. Imp. Nat. Mosc. 31,2: 436 (1858), non Eckl. \& Zeyh. (1836); Oxalis minima Sond. in Fl. Cap. 1: 336 (1860), nom. illegit. non Steud. (1821), nec G.Don (1831), nec Eckl. \& Zeyh. (1835); ['O. sonderiana (Kuntze) T.M.Salter' in J. S. Afr. Bot., Suppl. vol. 1:196 (1944), nom. superfl.]. Type: [South Africa, Namaqualand], Grootriet, Zeyher 237 (S11-2967, lecto. here designated; GRA0001610-1!, GRA0001610-2!, K000419345!, P00390732!, PRE0456167-1, SAM0030412!, W0009104!, isolecto.).

Note: Salter (1944:198) specifically states that the type of O. sonderiana (Zeyher 237) is in the Sonder Herbarium. The first set of the South African collections made by Ecklon \& Zeyher was acquired by Sonder. After Sonder's death, his herbarium was sold in several parts, the most important of which are currently housed at S and MEL. S houses the South African set of Ecklon \& Zeyher specimens (Stafleu \& Cowan 1985). A note on the sheet of Zeyher 237 at S indicates that it came from the Sonder Herbarium. We therefore choose this sheet as lectotype. Our choice is further supported by the fact that this specimen is well preserved and includes many flowering individuals. Unfortunately, this specimen does not contain bulb material, but it still represents the best material available as lectotype, with copies available in various international herbaria, including SAM.

\section{Identity of Oxalis beneprotecta and Oxalis bullulata}

A further taxonomic issue regarding southern African Oxalis taxa involves the identity and validity of $O$. beneprotecta Dinter ex R.Knuth and O. bullulata T.M.Salter. Oxalis beneprotecta is based on the type specimen Dinter 5182 from Namibia. Salter (1944:151) demoted this taxon to a variety of the widespread and variable O. pulchella Jacq., as O. pulchella var. beneprotecta (Dinter ex R.Knuth) T.M.Salter. It shares the typical O. pulchella characters of a large bulb $(3 \mathrm{~cm}-6 \mathrm{~cm}$ in length), well-developed papery bracts on the sturdy rhizome and hairy petioles, and appears to intergrade smoothly into the other varieties of $O$. pulchella. It differs from all other varieties of $O$. pulchella in being a smaller plant with a much larger number of leaves arranged in a rosulate basal tuft. Salter saw at least the type of O. beneprotecta (Dinter 5182) and also made several of his own collections of what he interpreted to be this taxon (Salter 1944:151). Regarding his own collections, Salter (1944) mentioned that:

Dinter's specimens are less hairy and have far fewer leaves than those from Louwspoort and Kamieskroon [Salter's Namaqualand collections], which were growing in rock crevices and had large distorted bulbs, but the two forms are evidently not separable. (p. 151)

Salter possibly considered his own collections as morphological intermediates to the Namibian forms, although it must be acknowledged that this is our interpretation.

Quite separately, Salter (1936:49) described the species Oxalis bullulata T.M.Salter based on the type specimen Salter 5552 
and synonymised the manuscript name 'O. parvicormus Dinter' based on Dinter 6372 (Dinter 1931:167) under it. He viewed it as a distinct species primarily because of the very different bulb - Oxalis bullulata has a small bulb (half to a third the length of the bulb of $O$. pulchella) with a characteristic puckered appearance to the tunics (to which the epithet 'bullulata' refers). Both O. pulchella var. beneprotecta and O. bullulata were maintained in the Salter $(1944: 151,164)$ monograph on Oxalis, and there is no question that he considered these entirely separate entities.

Schreiber $(1966: 5 ; 1967: 296)$ revised the Namibian species of Oxalis and rejected the taxonomic placements by Salter (1936:49). She accepted O. beneprotecta as a good taxon at species level and synonymised O. bullulata and O. parvicormus under this species. Having examined three isotypes of O. bullulata, Schreiber (1966:5) further stated her certainty that $O$. bullulata is identical to $O$. beneprotecta and therefore synonymised the former under the latter, despite the demonstrable morphological differences. Despite acknowledging that she had never seen Salter's Namaqualand specimens of O. bullulata, and stating that they may not belong to O. beneprotecta, Schreiber (1967:296) nevertheless still listed them under $O$. beneprotecta. These taxonomic changes were accepted in the List of Species of Southern African Plants by Gibbs Russel et al. (1987:99), from where they were propagated to many databases, both in South Africa (BODATSA and the Red List of South African Plants) and internationally (e.g. Tropicos).

We here wish to clarify the taxonomic confusion surrounding these taxa by accepting the circumscriptions of Salter (1936:49; 1941:167; 1944:151, 164). The morphological differences between the two taxa as described above are clear from the type specimens (digital versions available at http:/ / ww2.bgbm.org / herbarium/images/B/10/01/59/92/b_10_0159928.jpg and http:/ / plants.jstor.org/stable/10.5555/al.ap.specimen.bol1364 46 ? searchUri=filter $\% 3$ Dname $\% 26$ so $\% 3$ Dps_group_by_ genus_species\%2Basc\%26Query\%3Doxalis\%2Bbullulata). Our morphological assessment based on other herbarium collections in the STEU, NBG, SAM and BOL herbaria, and many field samples, has confirmed the separate identities of $O$. beneprotecta and O. bullulata beyond reasonable doubt. Oxalis bullulata is, morphologically at least, a good species worthy of recognition, and the manuscript name 'O. parvicormus' (based on Dinter 6372 ) is a synonym thereof. We are less certain of the taxonomic level at which to recognise Oxalis beneprotecta - it might very well be a species separate from $O$. pulchella, although it has many morphological similarities with this species. The precise species boundaries here require greater sampling as well as the acceptance of a coherent species concept for this morphologically variable genus. Until such data are available, we prefer to retain $O$. beneprotecta as a variety of O. pulchella, as O. pulchella var. beneprotecta (R.Knuth) T.M.Salter.

Oxalis bullulata T.M.Salter in J. S. Afr. Bot. 2: 49 (1936). Type: South Africa, Namaqualand, 10 miles north-west of Steinkopf, Salter 5552 (BOL136446!, holo.; K000417359!, NBG0107089-0!, iso.).
['O. parvicormus Dinter' in Repert. Spec. Nov. Regni Veg. 29: 167, 168 (1931), nom. nud. as for: Südwestafrika [Namibia], Buchuberge, Küstengebiet, Dinter 6372 (M0172240!); Buchuberg, S.W. Africa, Dinter 6472 (SAM0072757!)]

Oxalis pulchella Jacq. var. beneprotecta (R.Knuth) T.M.Salter in J. S. Afr. Bot., Suppl. vol. 1: 151 (1944); O. beneprotecta Dinter ex R.Knuth in Pflanzenr. (Engler) Oxalidac.: 355 (1930). Type: [Namibia], Vahldorn, Dinter 5182 (B 10 0159928!, holo.; AMD.82867!, BOL136447!, HBG509416!, HBG509417!, M0108543!, PRE0454873-1!, PRE0454873-2!, PRE0454873-3!, PRE0454873-4!, SAM0072763-0!, iso.).

Note: The sheet of the holotype at B has been wrongly encoded on www.plants.jstor.org as Dinter 5162. The sheet at SAM has been wrongly encoded as Dinter 5782 .

\section{Acknowledgements}

Dr Hugh Glen is thanked for assisting with Latin translations. Two anonymous reviewers are thanked for suggesting improvements to the manuscript.

\section{Competing interests}

The authors declare that they have no financial or personal relationships that may have inappropriately influenced them in writing this article.

\section{Authors' contributions}

L.L.D. and K.C.O. studied and compared the plant material of all relevant specimens. R.R.K. provided the impetus for the paper by initially querying the correct author citation of $O$. sonderiana and assisted considerably with the more complex aspects of the nomenclature. L.L.D. wrote the manuscript, and both co-authors commented on two drafts thereof.

\section{References}

Dinter, K., 1931, 'Kurzer Bericht über meine Reise 1929 in die Küstenwüste SW-Afrikas, spez. die Buchuberge', Feddes Repertorium 29, 167.

Don, G., 1831, A general history of the dichlamydeous plants: Comprising complete descriptions of the different orders...the whole arranged according to the natural system, J.G. and F. Rivington, London.

Ecklon, C.F. \& Zeyher, C.L.P., 1835, Enumeratio plantarum Africae australis extratropicae: Quae collectae, determinatae et expositae I, Prostat apud Perthes extratropicae: Quae
$\&$ Besser, Hamburg.

Gibbs Russel, G.E., Welman, W.G., Retief, E., Immelman, K.L., Germishuizen, G., Pienaar, B.J. et al., 1987, List of species of southern African plants Part 2 Dicotyledons, Memoirs of the Botanical Survey of South Africa No. 56, Botanical Research Institute, Pretoria.

Knuth, R., 1930, 'Oxalidaceae', in A. Engler (ed.), Das Pflanzenreich, vol. 4, 130, pp. 1-481, Wilhelm Engelmann, Leipzig.

Kuntze, C.E.O., 1891, Revisio generum plantarum, Arthur Felix, Leibzig.

Macbride, J.F., 1934, 'New or renamed Spermatophytes mostly Peruvian II', Candollea 6, 1-19.

McNeill, J., Barrie, F.R., Buck, W.R., Demoulin, V., Greuter, W., Hawksworth, D.L. et al., 2012, International code of nomenclature for algae, fungi, and plants (Melbourne Code) adopted by the Eighteenth International Botanical Congress Melbourne, Australia, July 2011, Koeltz Scientific Books, Königstein. [Regnum Vegetabile 154]

Salter, T.M., 1936, 'Plantae Novae Africanae Series V', Journal of South African Botany 2, 1-18.

Salter, T.M., 1941, 'Some notes on Oxalis pulchella Jacq. and its varieties', Journal of South African Botany 7, 163-168. 
Salter, T.M., 1944, 'The genus Oxalis in South Africa: A taxonomic revision', Journal of South African Botany, Suppl. 1, 1-355.

Schreiber, A., 1966, 'Oxalidaceae', Prodromus einer Flora von Südwestafrika 63, 1-8.

Schreiber, A., 1967, 'Die Gattung Oxalis L. in Südwestafrika', Botanische Jahrbücher 86, 293-308.

Sonder, O.W., 1860, 'Oxalidaceae', in W.H. Harvey \& O.W. Sonder (eds.), Flora Capensis I, pp. 318-348, A.S. Robertson, Cape Town.
Stafleu, F.A. \& Cowan, R.S., 1985, Taxonomic literature: A selective guide to botanical publications and collections with dates, commentaries and types, vol. 5, 2nd edn., Bohn, Scheltema \& Holkema, Utrecht, [Regnum Vegetabile 112]

Steudel, E.G., 1821, Nomenclator botanicus: Enumerans ordine alphabetico nomina atque synonyma, tum generica tum specifica, et a Linnaeo et recentioribus de re botanica scriptoribus plantis phanerogamis imposita, I.G. Cottae, Stuttgart.

Turczaninow, N., 1858, 'Animadversiones in Secundam Partem Herbari Turczaninowiani, nunc Universitatis Caesareae Charkowiensis', Bulletin de la Société Impériale des Naturalistes de Moscou 31(1\&2), 185-476. 